\title{
IAMJ
}

INTERNATIONAL

AYURVEDIC

MEDICAL JOURNAL

(b) $\bigcirc(1$

\section{CASE REPORT ON MANAGEMENT OF AMAVATA W.S.R RHEUMATOID ARTHRITIS}

\author{
Bhagyashree P. Bramhanwade ${ }^{1}$, Archana S. Dachewar ${ }^{2}$
}

${ }^{1}$ MD Scholar Department of Kayachikitsa, Shri Ayurved Mahavidyalaya, Nagpur, Maharashtra, India

${ }^{2}$ Guide, Professor and HOD Department of Kayachikitsa, Shri Ayurved Mahavidyalaya, Nagpur, Maharashtra, India

Corresponding Author: bramhanwade93@gmail.com

\section{https://doi.org/10.46607/iamj15p6012021}

(Published Online: November 2021)

Open Access

(C) International Ayurvedic Medical Journal, India

Article Received: 31/10//2021 - Peer Reviewed: 07/11/2021 - Accepted for Publication: 08/11/2021

Check for updates

\begin{abstract}
Amavata is a second common joint disorder. Amavata is a disease of Rasavaha Strotas. It is mainly produced due to Ama and vitiation of Vata Dosha. According to the clinical features, Amavata is compared with Rheumatoid arthritis. Rheumatoid arthritis is a chronic, progressive autoimmune arthropathy. This disease affects the mainly young population. Hence it is a most burning problem in society. Ayurveda has taken the foremost place in the management of many diseases one of them is Amavata. Here an effort was made to treat the male of age 47 years, using multiple ayurvedic treatments. A diagnosed patient is treated with Sin Hand Guggul, Mahasudarshan With, Eranda Tail, Valuka Pottali Sweda, Sanshmani Vati. The end of the 60th day of treatment resulted in the improvement of overall symptoms.
\end{abstract}

Keywords: Amavata, Ama, Sinhanaad Guggul, Valuka Pottali sweda, case report

\section{INTRODUCTION}

Amavata is a lifelong disease caused due to formation of the Ama (toxin) and vitiation of the Vata along with the Kapha-sthana in the body. The Sleshma sthana are primarily the synovial joints. The vitiated Vata circulates the Ama all around the body through the
Dhamanis and resides in the Sleshma-sthana inducing sandhishotha, sandhishoola, sancharivedana in small as well as big joints. Amavata broadly resembles rheumatoid arthritis which is an extremely debilitating condition. Rheumatoid arthritis is a chronic, progressive, 
inflammatory systemic disease affecting the synovial joints with extra-articular manifestations ${ }^{[1]}$. The characteristics mainly include joint pain, stiffness, tenderness and restricted movements. As per Ayurveda, the disease is produced due to vitiation of the Tri-doshas by Ama and Vata. Acharya Chakrapani has detailed the principles of treatment for Amavata ${ }^{[2]}$. Langhana, Swedana, Tikta- Katu rasa dravyas, Deepana dravyas, Virechana and Anuvasana Basti are some treatment modalities beneficial in Amavata. Perhaps, the progressive disease is found difficult to manage despite the best available drugs in modern. And Ayurveda does provide a safer, economic and effective treatment for Amavata. Accordingly, a treatment protocol was designed and administered to the patient and that is described below.

Aim and Objectives: Efficacy of internal ayurvedic medicines and panchakrma in the management of patients suffering from amavata admitted to the ayurvedic hospital

\section{MATERIAL AND METHODS}

The study was planned at Shree Ayurved College \& Hospital, Nagpur. The study was carried out ethically as per GCP (Good Clinical Practices) guidelines.

\section{CASE REPORT:}

A male patient of age 47 years visited the Kayachikitsa O.P.D. of our hospital on 05/04/2019 with O.P.D. no. 18785 with complaints of Shoola, Shotha and Sthambha in multiple joints for 2 months

Vartmanvyadhivrutta: A 47years male patient faced complaints of Shoola (pain) and Sthambha (stiffness) at the metacarpophalangeal joint of both hands. Gradually, he developed the same pain and stiffness in both the knee and wrist joints. He later suffered from Shotha (swelling) over affected joints on and off. Eventually, the elbow and ankle joints also began to get affected. Also, decreased appetite and unsatisfactory bowels added up to the illness. He was temporarily relieved by the allopathic anti-inflammatory medications and sooner begin to develop the symptoms again. Thus, the patient then approached our hospital for further treatment.
History of Past Illness: No history of Diabetes, h/o Hypertension or any major illness.

Family history: The patient's father had a history of Arthritis and Diabetes.

Personal History:

- Ahara: Samishra ahara. (Mixed diet)

- Vihara: Divaswapa, Ati-charana

- Nidra: Madhyama

- Mala pravritti: Asamyaka (Unsatisfactory)

- Mutra pravritti: Samyaka (Satisfactory)

- Vyasana: Tea (4-5 times a day)

\section{Ashthavidha Parikshana:}

- Nadi: 78/min

- Mala: Asamyaka, Vibandha (Constipation)

- Mutra: Samyaka

- Jivha: Sama

- Shabda: Spashta

- Sparsha: Ushna (Alpa)

- Druka: Spashta

- Akruti: Madhyama

\section{General Examination}

Vitals: Pulse rate: $78 / \mathrm{min}$

Blood pressure: 130/80 mm

Temperature: $98.2 \mathrm{~F}$

Respiratory rate: $18 / \mathrm{min}$

\section{Systemic examination:}

On examination, the patient is conscious, afeb.

$\mathrm{RS}=\mathrm{NAD}, \mathrm{CVS}=\mathrm{S} 1, \mathrm{~S} 2$ Normal

Local examination: On examination of the musculoskeletal system, marked pitting oedema was found on bilateral wrist joints, knee joints and face. On palpation, tenderness was observed on the wrist and metacarpophalangeal joints. No joint deformity was found. Blood investigation: The routine blood investigations of the patient were found to be -

$\mathrm{Hb}-9.4 \mathrm{gm} / \mathrm{dl}$

ESR $-80 \mathrm{~mm}$ at end of 1 hour

RA factor - Reactive

DLC, TLC, S. Uric acid values were within normal limits. 


\section{TREATMENT}

Total Duration- 90 days with every 15 days follow up.

\begin{tabular}{|l|l|l|}
\hline Treatment & Medicine & Dose \\
\hline Internal treatment & Sinhanaad guggul & 2 tablets thrice daily \\
\hline & Shanshmani vati & 2 tablets twice daily \\
\hline & Mahasudrashan kwatha & 3 tsp twice daily \\
\cline { 2 - 3 } & eranda tail & 10 ml every night \\
\hline External treatment & Valuka Pottali sweda & Twice daily \\
\hline
\end{tabular}

ASSESSMENT CRITERIA

Subjective Parameters:

\begin{tabular}{|c|c|c|c|c|c|}
\hline Symptoms & $\mathbf{0}$ & 1 & 2 & 3 & 4 \\
\hline Jwara & Absent & Mild & Moderate & High & Hyperpyrexia \\
\hline Aruchi & Absent & Occasional & Intermittent & Often & Always \\
\hline $\begin{array}{l}\text { Anga- } \\
\text { marda }\end{array}$ & Absent & Occasional & Intermittent & Often & Always \\
\hline $\begin{array}{l}\text { Sandhi- } \\
\text { shola }\end{array}$ & $\begin{array}{l}\text { No } \\
\text { pain }\end{array}$ & $\begin{array}{l}\text { Mild pain, bear- } \\
\text { able }\end{array}$ & Moderate pain & $\begin{array}{l}\text { Severe pain } \\
\text { with slight difficulty } \\
\text { in movements }\end{array}$ & $\begin{array}{l}\text { Severe pain } \\
\text { with more difficulty } \\
\text { in movements }\end{array}$ \\
\hline $\begin{array}{l}\text { Sandhi } \\
\text { shotha }\end{array}$ & Absent & $\begin{array}{l}\text { Mild, >10\% } \\
\text { increased } \\
\text { circumference } \\
\text { of affected } \\
\text { joint }\end{array}$ & $\begin{array}{l}\text { Moderate, }>10 \% \\
\text { increased } \\
\text { circumference } \\
\text { of affected joint }\end{array}$ & $\begin{array}{l}\text { Severe, }>20 \% \\
\text { increased } \\
\text { circumference } \\
\text { of affected } \\
\text { joint }\end{array}$ & $\begin{array}{l}\text { Severe, }>20 \% \\
\text { Increased } \\
\text { Circumference } \\
\text { of affected } \\
\text { Joint }\end{array}$ \\
\hline
\end{tabular}

\section{Objective Parameter}

\begin{tabular}{|l|l|}
\hline Haematological tests & Normal range \\
\hline RA FACTOR & $<20 \mathrm{IU} / \mathrm{ml}$ \\
\hline ESR & Male $-0-9 \mathrm{~mm} / \mathrm{hr}$ \\
& Female $-0-20 \mathrm{~mm} / \mathrm{hr}$ \\
\hline HB & Male $-14-18 \mathrm{~g} / \mathrm{dl}$ \\
& Female $-12-16 \mathrm{~g} / \mathrm{dl}$ \\
\hline
\end{tabular}

\section{OBSERVATION}

\begin{tabular}{|l|l|l|}
\hline Symptoms & BT & AT \\
\hline Jwara & 2 & 0 \\
\hline Aruchi & 4 & 1 \\
\hline Angamarda & 3 & 0 \\
\hline Sandhi shola & 3 & 1 \\
\hline Sandhi shoth & 3 & 1 \\
\hline
\end{tabular}

\section{Haematological parameters:}

\begin{tabular}{|l|l|l|}
\hline Parameters & Before treatment & After treatment \\
\hline Haemoglobin $(\mathbf{g m} / \mathbf{d l})$ & $\mathbf{9 . 4}$ & $\mathbf{1 1 . 2}$ \\
\hline ESR $(\mathbf{m m}$ at end of 1 hour $)$ & $\mathbf{8 0}$ & $\mathbf{3 0}$ \\
\hline RA factor & Positive & Negative \\
\hline
\end{tabular}




\section{DISCUSSION}

Chakradatta was the first, who described the Chikitsa Siddhant for Amavata ${ }^{[3]}$. It includes Langhana, Swedana, drugs having Tikta, Katu Rasa and Deepana action, Virechana, Snehapana and Anuvasana as well as Ksharabasti. Amavata is considered to be an Amashayotha vyadhi and Rasaja Vikara. Langhana is the first line of treatment in such conditions. In Yogaratnakar Langhana has been mentioned to be the best measure for the treatment of Ama. In Amavata, Rukshasweda has been advocated in the form of $\mathrm{Val}$ ukapottali due to the presence of Ama. It helps in pacifying vitiated Vata Dosha thus leading to relieving pain and stiffness. Sinhanaad Guggul is mentioned specifically for the treatment of Amavata in Bhaishyaratnavali. Simhanada Guggul has Laghu, Ruksha, Ushna, Tikshna properties. The majority of drugs of Simhanada Guggul have Deepan (enzyme activating), Ama-Pachan (biotoxin neutralizing), Shothaghna (oedema reducing), Shoolghna (analgesic), Jwaraghna (antipyretic) and Amavatahara (antirheumatic) properties. This helps in breaking the Samprapti (pathogenesis) of Amavata. The Eranda tail was administered for Amapachana and Agni- deepana properties. Mahasudarshan kwath has anti-inflammatory, antipyretic, ama-pachan and deepan properties. Sanshanmani vati contains guduchi which has antirheumatic, antipyretic and rasayana properties. Valuka-Pottali sweda ${ }^{[4]}$ was given for external dry fomentation which induces sweating which helps relieve the pain and stiffness of the joints making them mobile and free for movements. The assessment of the patient before and after treatment was taken which showed improvements in the subjective and objective criteria.

\section{CONCLUSION}

The case report shows that combined ayurvedic treatment is potent and effective in the management of amavata. There were no adverse effects found in combined ayurvedic treatment. Hence Amavata can be effectively and safely treated by using Chikitsa Siddhant described by Ayurveda.

\section{REFERENCES}

1. Shah Ankur, E. William St. Clair, Harrison's Principles of Internal MedicineVolume 2, 18th edition, Chapter 321, Rheumatoid Arthritis, (Pg. 2739).

2. Sri Chakrapanidatta's Chakradutta with Vaidayaprabha, Hindi Commentary and notes, introduction, indices, appendices etc by Dr Indradeva Tripathi, Varanasi, Chaukambha Sanskrit Bhawan, reprint edition, 2018, Chapter 73, Niruhadhikar 73/32, Page 455.

3. Chakrapani Datta. Chakradatta commentary by Indradev Tripathi.Amavatarogadhikara 25/31-36. Varanasi: Chaukhamba Sanskrit Sansthan; 2010. (Pg. 167168).

4. Dr.G. Shrinivasa Acharya (2006), Panchakarma illustrated, $1^{\text {st }}$ edition, Delhi, Chaukhamba Sanskrit Pratisthan, Baluka sewdana, Page 215.

\section{Source of Support: Nil Conflict of Interest: None Declared}

How to cite this URL: Bhagyashree P. Bramhanwade \& Archana S. Dachewar: Case Report On Management Of Amavata W.S.R Rheumatoid Arthritis. International Ayurvedic Medical Journal \{online\} 2021 \{cited November 2021\} Available from: http://www.iamj.in/posts/images/upload/3254_3257.pdf 